\title{
The EU and Belarus: democracy promotion by technocratic means?
}

\author{
Professor Elena A. Korosteleva
}

School of Politics and International Relations

University of Kent

Email: eak8@ketn.ac.uk

\begin{abstract}
Is Belarus an enviable constant in international relations: a maverick, isolated from the West and inseparable to the East? On the surface, there seems to be business-as-usual: Lukashenko's regime remains unchallenged; Belarus' relations with the EU - spasmodic at best; while its absorption into Russia's Eurasian project continues apace. Yet, some critical disjunctures - manifested in government tacit resistance to Russia's influence, and more instructively, in people's growing affinity with Europe - may indicate a sea-change transformation in the very fabric of society. This paper, utilising extensive and subject-focused research, conducted in the country between 2009 and 2013, examines the nature and causalities of the occurring change. It argues that democracy promotion, in Belarus' case, may work better when depoliticised and inculcated, through norms, regulations and practices of international order, into the daily lives of individuals. Through its continued technocratic, inclusive and sector-level engagement, EU governance, even under the conditions of limited bilateral dialogue, have succeeded in fostering much-needed space for reciprocal learning and critical reasoning, which may have far greater transformative potential than manufacturing a single collective will for democracy-building.
\end{abstract}


The EU and Belarus: democracy promotion by technocratic means?

\section{The EU and Belarus: democracy promotion by technocratic means?}

\section{Introduction: 'still waters' or incremental change?}

Is Belarus an unwavering constant in international relations: an authoritarian maverick, continuously isolated from the West, and increasingly entangled into the Russian - now Eurasian - sphere of influence? Indeed, on the surface, there seems to be business-as-usual: for two decades Freedom House has referred to the country as 'the least free, or fair' in Europe, ${ }^{1}$ while scholarly accounts customarily depict it as 'the last dictatorship in Europe', ${ }^{2}$ with Alexander Lukashenko remaining as de facto President since 1994.

Belarus's relations with the international community and especially, with its larger western neighbour - the European Union (EU) - have shown little sign of change since the mid-1990s, and at best could be described as spasmodic: for every intention to cooperate, there always seems to be a counter-action to thwart it. For example, an initially enthusiastic ratification of Belarus' Partnership and Cooperation Agreement (PCA) with the EU in 1995, ended in suspension only two years later, owing to its declining human rights record. ${ }^{3}$ A subsequent rapprochement in 1999 - as part of the 'Responsible Neighbourhood' strategy - instead concluded in the signing of a Union Treaty with Russia. ${ }^{4}$ Efforts for more dialogue under the European Neighbourhood Policy (ENP) in 2004 and a subsequent Eastern Partnership Initiative (EaP) in 2009, ${ }^{5}$ yielded only partial involvement of Belarus, in a nonbinding multilateral track of regional cooperation. A Joint Interim Plan carrying substantial financial incentives, but straightjacketed by political conditionality, ${ }^{6}$ disintegrated after the 2010 presidential election. The 2012 Dialogue on Modernisation, targeting civil society, to date, as claimed, has had only a limited effect. ${ }^{7}$ A sense of impasse around the EU-Belarus relations has now grown into a sense of fatigue amongst policy-makers, donors and even practitioners, resulting in half-measures

normally short of action and commitment. ${ }^{8}$ Donors are particularly wary of Belarus-focused discussions, and presently there seems to be a tacit acceptance of the established status-quo 
The EU and Belarus: democracy promotion by technocratic means?

Meanwhile, Belarus' relations with its eastern neighbours have predictably expanded, albeit more often through compulsion, rather than by free will. By 2007 Belarus was co-opted into negotiation over the Eurasian Customs Union (ECU) with Russia and Kazakhstan, which took force in $2010 .{ }^{9}$ By May 2014 the ECU member-states signalled a joint agreement on the prospective launch of the Eurasian Economic Union (EEU), to come into effect in January 2015. ${ }^{10}$

So, as it seems, Belarus' domestic and international relations remain emphatically stagnant reflecting a predictable status-quo, or do they?

Two critical disjunctures challenge a seemingly enduring order. The first disjuncture refers to government quiet but persistent discourse of resistance to Russia's overbearing influence, manifested in three long years of sabotaging the launch of the ECU and petty wars over trade and economic issues, ${ }^{11}$ in re-shaping the Eurasian course into a cumulative integration narrative to stay connected with both the East and the West; ${ }^{12}$ in a recently increasing dialogue with the $\mathrm{EU},{ }^{13}$ and more tellingly, in publicly endorsing Poroshenko's leadership in Ukraine and objecting to Russia's demands of extending economic and political embargo to the country. ${ }^{14}$

The second disjuncture is by far more emblematic of existing undercurrents at work, exposing profound longitudinal changes ${ }^{15}$ in public opinion and behaviour associated with growing levels of affinity and interest in the EU, as well as the public's gradual legitimation of European standards and fostering of a new European identity -'We are part of Europe', a narrative hitherto absent from a public 'story-telling'. This indicates an ongoing process of socialisation into a European discourse and a wider European space, manifested at different levels and by different actors. In turn, this may also suggest that the EU, despite a limited official dialogue, might have been doing something 'right', to be able to succeed in expanding the boundaries of public space and even engendering a new sense of identity. This triggers a range of questions, with three perhaps being of particular relevance: 1) what has been the EU's strategy to date, especially in the circumstances of no political dialogue; 2) how does this translate into public/government narratives; and 3) essentially, if there are changes, why now and what of democracy? 
The EU and Belarus: democracy promotion by technocratic means?

Hence, this article sets to examine recent changes in EU policy towards the region, and Belarus in particular, to uncover causalities at work, which may be, at least partially, responsible for the occurring social transformation in the country. In particular, the article contends that the 'opening' in government and public narratives - the 'story-telling' of their daily lives - is a consequence of continuing and persistent practice of engagement by the EU, but not through high-level politics and value-taxing conditionality. This proves some vocal critics wrong about 'betraying' EU values 'when partnering dictatorships'. ${ }^{16}$ Instead it is rather the enablement via codified, regulatory and interestdriven exposure of individuals at different levels, through sector cooperation, to the workings of European democracy, which makes a difference. These changes, reflected in altering patterns of public behaviour and a growing sense of identity, necessitate further discussion of democracy promotion as a non-linear process of social empowerment which works with local issues on an individual level, and of international assistance, which inculcates international norms into people's daily practices and narratives, thus approximating their space to that of 'the international'. Whatever the assumptions or their justifying rationalities, they invariably challenge the established political (value-driven) underpinnings for democracy promotion, and necessitate a discussion of social empowerment anew, and by other means, which are uncovered below.

\section{The EU approach: towards social empowerment and norm codification}

Since the launch of the ENP in 2004, the EU had struggled to secure allegiance from the partner countries in the east. ${ }^{17}$ The policy went through several iterations with the same limited effect: its further differentiation, including the EaP initiation, raised more concerns than provided solutions to the dwindling support in the eastern neighbours. ${ }^{18}$

In 2011, however, the Commission substantively revisited its approach to the eastern region, ${ }^{19}$ which marked a turning point in EU engagement. ${ }^{20}$ Three particular aspects are worth noting here: Firstly, the new measures have become more complex and versatile, expanding the panoply of instruments, programmes and actors, to lock partners into an enduring reciprocal relationship. Secondly, the new approach became more inclusive in targeting all levels of society, especially regionally and locally, 
The EU and Belarus: democracy promotion by technocratic means?

ensuing EU visibility and internalisation of European standards. Thirdly, and perhaps most instructively here, the EU approach has become more technical, sector-driven, and low-key, gradually depoliticising conditionality, but enabling norms' codification and their inculcation into the daily practices of Belarusian people. Let us observe the context of the occurring change.

The 2011+ iteration of the EaP approach turned a two-track approach into a complex matrix of enablement, supported by a new 'more for more' format of cooperation. ${ }^{21}$ Primarily, the bilateral track offered legally binding Association Agreements (AA) to the willing parties, which, after a series of recent setbacks and postponements, have now been signed with Ukraine, Georgia and Moldova. ${ }^{22}$ The AAs, structured along the three principal dimensions of fostering Political Association/Free Trade Area (DCFTA), Mobility Partnerships, and Sector Cooperation, lay ground for an ambitious integrationist agenda, especially in terms of expanding the single European market and making EU institutional structures more accessible. ${ }^{23}$ These binding initiatives were supported by a wide range of financial instruments and structural programmes, including the European Neighbourhood Instrument $(\mathrm{ENI}){ }^{24}$ the Neighbourhood Investment Facility, the EAP Integration and Cooperation Facility, Civil Society Facility (CSF), European Endowment for Democracy (EED), European Investment Bank's (EIB) external mandate and the EU-financed Council of Europe Eastern Partnership Facility, which jointly approximated $€ 1$ billion in loans and grants for 2011-13 alone $!^{25}$ Admittedly, the EU bilateral track does not officially apply to Belarus. At the same time, the EU succeeded in making important contractual inroads into the country, via technical assistance and sector cooperation, amounting to almost $€ 60$ million under the ENPI for $2012-13$ alone ${ }^{26}$ thus relating to a six-fold increase in funding available for 2007-11. The range of structural programmes has also expanded. In particular, the bilateral 2012-13 roadmap for Belarus aimed at enhancing mobility and sector-cooperation. The ensuing talks on visa facilitation (including bilateral actions of individual member states) and readmission agreements gradually yielded positive response from the government. ${ }^{27}$ Under sector cooperation the EU has initiated talks on the Baltic Energy Market Interconnection Plan to establish a regulatory and institutional framework promoting energy 
The EU and Belarus: democracy promotion by technocratic means?

efficiency and increasing renewable energy use (C.2.a.) and has introduced a strategic framework for EU-Belarus customs cooperation which was agreed and endorsed in 2011 (C.7). ${ }^{28}$ Belarus was also included as an observer to the Northern Dimension Partnership; and is now an active participant of the Partnerships on Environment and on Transport and Logistics. The Market Economy Status assessment, launched in Belarus in 2010, prepares the ground for structural reforms and economic stabilisation. To address regional economic and social disparities new pilot regional development programmes were recently added ${ }^{29}$ offering over $€ 10$ million in support and investment. This is in complementarity to the Comprehensive Institution Building (CIB) programmes addressing public administration reforms, which totalled to $€ 5$ million for $2012-13$. The Delegation of the European Commission to Belarus was upgraded to a fully-fledged EU Delegation in the course of 2011, and is now an active interlocutor between the government and non-state actors in Belarus. The EIB has also extended its lending mandate to Belarus, which assistance has at a minimum increased twofold since $2010 .^{30}$

These concrete roadmap targets - although still officially limited in scope and coverage - do not simply aim to lock partners into a 'more for more' modality of cooperation and self-censorship; they also promote decentring and local initiative which embrace all levels of society - civil society, businesses, local authorities, central government and national parliaments. This has clearly facilitated some local activism in Belarus, especially amongst business interests and non-state actors. ${ }^{31}$

At the same time, Belarus' full engagement with the EU has been chiefly facilitated by the EaP multilateral track. ${ }^{32}$ Since 2011 the track has come to operate its own instruments and infrastructure. ${ }^{33}$ It is precisely its inclusive nature that allows further individuation of EU policies in support of local activism and democracy. Notably, in all six EaP countries, CSF, national platforms, Business Forum, ${ }^{34}$ CORLEAP, ${ }^{35}$ and EURONEST ${ }^{36}$ have provided CS organisations and other stakeholders with a chance to articulate their needs, and facilitate reforms at the individual countries' level. Many local actors are now regular and active participants in various EaP informal and formal consultations and meetings. ${ }^{37}$ 
The EU and Belarus: democracy promotion by technocratic means?

This panoply of instruments and actors (especially CSF, EED and special measures) have continuously covered Belarus, including at the time of diplomatic crises which followed the 2010 and 2012 elections. Through thematic platforms alone, Belarus received in aid over $€ 300$ million worth of funding (some ongoing since 2001), having become fully integrated in good governance, people-to-people, and socio-economic projects. ${ }^{38}$ A European Dialogue on Modernisation with Belarusian society was launched at the Commission's initiative on 29 March 2012, ${ }^{39}$ and now involves, via specific projects, over 747 non-governmental organisations alone who engage with EUlevel activities. ${ }^{40}$ The Dialogue offers exchange of views and inculcation of EU practices into variouslevel stakeholders. The agenda of meetings is set by the Belarusian stakeholders, identifying priorities for support and investment in the forthcoming years; and the language of decision-making is outputdriven, and codified to European standards. The first meeting of the Dialogue took place in Poland on 16-17 April 2012 and focused on the issues of privatisation and entrepreneurship. ${ }^{41}$ In 2013 the Dialogue, for example, initiated two new programmes for Belarus: BELMED - supporting reforms in the healthcare system ( $€ 8$ million) and RELOAD-2 offering support for regional and local development in two regions - Grodno and Minsk (€3,5 million). Although limited in terms of direct contact with higher-levels officials, the Dialogue is effective at lower levels (including respective Ministries), and helps regional authorities, in particular, to identify and promote development strategies, and support local communities through training and grant-identifying strategies. ${ }^{42}$ As the Belarusian Ministry of Foreign Affairs confirms, there are currently 59 ongoing projects (with over 150 successfully completed in the past ten years, and many ongoing on the EC assessment!) being implemented in Belarus under EaP initiatives, especially in the areas of border modernisation and customs infrastructure, energy, transport, environment, education, and culture, which overall budget has quadrupled since $2010 .{ }^{43}$

Finally, and most importantly, many of these initiatives simply focus on sector cooperation, avoiding high-level politics and instead connecting multiple stakeholders, within and outside the country, to encourage their socialisation into international practices, and to facilitate an independent mode of 
The EU and Belarus: democracy promotion by technocratic means?

thinking. As Petrova and Raube observe, ${ }^{44}$ a single added value of EURONEST is perhaps less about the output, but much more about the process of their communication, which enables a new language of norms, new narratives of deliberations, and prospectively, a new modus operandi, conducive to fostering reciprocal learning space and future dialogue. This mode of engagement - low-key, depoliticised and technocratic - is relatively new, but already proved effective by enabling a greater number of local actors, and increasing their levels of awareness, appreciation and affinity with EU standards, as the next section conveys. It is perhaps unsurprising that the EU bilateral initiatives for Belarus for 2014-17 propose to include projects focusing on social inclusion, environment, and local and regional economic development, with the indicative support of $€ 90$ million, ${ }^{45}$ which if anything, should further enable reasoned and responsive citizenship and raise awareness about people's social rights and economic benefits of cooperation. In this framing, the technocratic means of democracy promotion becomes social empowerment, rather than a defeat of EU normative agenda, as some commentators of this approach would contend. ${ }^{46}$

The above examination of the advantages of the continued EU technocratic engagement is not at all to claim that this non-linear approach has been impervious to fallacy: the events in Ukraine explicitly challenge this position. It is clear that the complex and inclusive matrix of engagement, although innovative and versatile in the opportunities it offers, still lacks the mechanisms of ensuring implementation and commitment to the course. It also struggles to outpace Russia in offering, and committing partners to accept alternative choices. At the same time, and no matter how imperfect the overall model of EU external engagement still is, it is a decisive step forward in trying to engage more inclusively, predicating on the needs of partner countries and their people. Belarus' case is very instructive here: despite the overall lack of strategy, and political dialogue, the aforementioned activities have triggered some substantial undercurrents, which may with time, erode the existing architecture of the deadlocked relations between the EU and Belarus, nudging the latter towards more dialogue and cooperation. As Commissioner Füle has commented, the EaP, despite its setbacks and shortcomings, offers a much-needed 'inclusive process' of enablement and allows countries like 
The EU and Belarus: democracy promotion by technocratic means?

Belarus, deterred by other commitments, still to be part of the wider European project. ${ }^{47}$ These of course may well be far-reaching objectives, especially in the light of the immense damage cause by the war in Ukraine, Russia's annexation of Crimea and a continued regional dispute between the EU and Russia. Nevertheless, the changing modus operandi does help to reignite hopes and combat decision-making fatigue vis-à-vis Belarus at the international level. No matter how small-scale or confined the above activities may seem, they reveal what 'still waters' hide well - the practices at work which are inspired by new instruments and actors, and which eventually may lead to the emergence of new social structures to challenge the seemingly inviolable surface of the existing status quo. How do the above activities translate into a public modus operandi?

\section{Population: EU legitimacy writ large?}

As discussed elsewhere ${ }^{48}$ public legitimation is one of the most essential requirements for fostering sustainable democracy. It works as a measure of acceptance and support for the established political order, a kind of subscription to a professed normative course. It also serves as a means to keep governments accountable, when it comes to evaluating their performance and deliberating on a new course. Hence, exploring the nature of public discourse as a composite of citizens' daily narratives is an important exercise, which may expose some causality at work and render a clearer view on public recognition of EU policy impact as well as the validity of government course, and the perception of the Self. All these aspects, in correlation with EU policy practices examined earlier, should shed a new light on the current debate about the nature and strategies of democracy promotion.

Based on extensive and subject-focused research, conducted in the country between 2009 and $2013,{ }^{49}$ which findings were also corroborated by a number of other sources, ${ }^{50}$ the following trends become identifiable via cross-temporal analysis of public behaviour and attitudes, and are explored below:

1) there has been a significant rise in public awareness and cognizance of the EU as a polity, its institutions and policies;

2) there is a growing sense of clarity and recognition of EU competencies in specific areas, and their mapping against the needs and interests of the population; 
The EU and Belarus: democracy promotion by technocratic means?

3) most essentially, a new sense of identity is forging premised on a more critical evaluation of the Self, acceptance of European standards, and interrogation of government rationale for one-dimensional policy eastwards. To this end, relations with Russia (and ECU) are no longer seen as a default option for Belarus.

First, a cross-temporal analysis of public opinion explicitly reveals a positive and substantive shift of preferences towards the EU, in cross-temporal comparison. This is primarily reflected in higher levels of awareness, more discernible knowledge of EU structures and policies, more interest in EU affairs, more appreciation of EU support and most importantly, more identity-based narrative vis-à-vis the EU. In particular, the levels of public awareness about the EU as a polity have reached 97 percent, an absolute majority ( +4 percent), allowing to facilitate a more discernible understanding of the EU structures, institutions and activities. Respondents display higher cognizance in detailing EU functions, policies and multi-level actors, in comparison with any other international organisations cited in the survey. They could name without difficulty all Member States of the EU, its key institutions and geographical outposts of power. This is further reinforced by growing interest in EU affairs (49 percent; +5 percent), against a similar drop in that of Belarus-Russia and the CIS. An astonishing two-fold increase is observable in the positive image of the EU within the country (55 percent). Twice as many respondents are now familiar with the EaP initiative (39 percent), and correctly name countries and their progress under the ENP framework. Moldova and Georgia are listed as the frontrunners, while Ukraine is observed as 'problematic' and Belarus as 'a laggard', 'to be ashamed of' (+ 4 percent). The EU is increasingly associated with 'hope' ( +5 percent) and 'enthusiasm' (+10 percent); replacing 'indifference' ( -6 percent) and 'mistrust' ( -3 percent) of the past.

Second, changing attitudinal positions of respondents also render greater clarity to EU objectives, policies and intentions towards the country, which translate directly into public appreciation and recognition of EU competencies in some specific areas, while mapping them against those of the ECU. Notably, EU support is now seen as more closely corresponding to the interests of both the 
The EU and Belarus: democracy promotion by technocratic means?

government and people (a two-fold rise since 2009), and there is an increasing overlap between what Belarusians perceive to be 'most pressing issues' of the day and where the EU could adequately help. More specifically, while living costs, working conditions, meagre pensions and a crumbling health system are regarded as imminently failing and in need of urgent support; Belarus is believed could learn more from the EU in the areas of economic reforms (81 percent), social protection (66 percent), effective governance (63 percent) and independent judiciary (61 percent). This is particularly striking when compared to a set of areas where the ECU's competencies and aid are believed to be complementary: trade (70 percent); economic reforms (51 percent), tourism (38 percent) and energy security (29 percent). This comparison indicates the EU's growing credibility with the general public; and deeper public understanding of the EU and ECU competencies. A clear mapping out of competencies of the EU and the ECU seems to have taken place in public narratives, and more than often, they are viewed in their distinctiveness and complementarity, allowing for the development of synergies and their legitimation.

Greater clarity about the EU intentions towards the country, in turn generates closer affinity with the former as a polity and a major power. In particular, a third of the respondents have now come to assert that the EU is an important strategic partner, which is comparable with those pledging support for the ECU and Russia (39 percent), with the latter historically enjoying strong public support. In public assessment of the EaP's relevance and effectiveness, twice as many respondents have found that partnership now fully corresponds to the interests of Belarus' government and its people. On average, a 10 percent rise is observed amongst those who affirm that the EaP is premised on common values (43 percent), common economic and political interests (39 percent), common security interests (45 percent), and mutual trust (56 percent). Further legitimation of the EU is manifested in a sharp two-fold decline in those respondents who initially contended that Belarus-EU cooperation was in the EU's interests only. A tenth of the population have heard about the programme on Modernisation initiated by the EU in March 2012. Many respondents noted a particular progress in the areas of trade, cross-border cooperation, student exchange, and economic opportunities; and a fifth pledged that this 
The EU and Belarus: democracy promotion by technocratic means?

cooperation fully corresponds to the interests of the peoples ( +7 percent). These rather affirmative reflections are radically different to those in 2009 , displaying more indifference and fear. In a relatively short period of time, the transformation in attitudinal and behavioural patterns is truly astounding, especially given the non-existent bilateral dialogue between the EU and Belarus under the EaP, and growing presence of the ECU and Russia in Belarus' domestic politics.

Third and most instructive, is the rise of a new critical identity amongst Belarusians. A new narrative, which expresses growing public affinity with the EU, can be summed up as 'We are Europeans', and 'We are part of Europe', which hitherto had no precedent. In parallel, changes in public selfperception also become apparent associated with a more critical (and even negative) view of Belarus' external policies, and its single-vector move eastward. In particular, an increasing number of respondents disapprove the course of Belarus' foreign policy ( +6 percent), and critically assess Belarus' image abroad (31 percent, a two-fold rise since 2009). Many believe that Belarus may no longer be seen as a suitable and important partner to their neighbours, and especially to the EU (52 percent, +5 percent). Some begin to view their country as a security threat to the neighbourhood ( +4 percent) expressing increasing vulnerability and a sense of insecurity about their future. It is important to note that this progressively negative self-assessment coincided with the increasing mobility of the population as a whole. A growing number of respondents now travel abroad $(+5$ percent), and have been to the EU more than once ( +4 percent). This is against a considerable decline of those (-20 percent) who had never travelled outside the country.

Russia and the ECU continue to be viewed favourably as Belarus' foreign policy priority, but this is no longer exclusive, and is manifested in many different ways. For example, when faced with the choice between the EU and Russia/ECU, the respondents no longer unequivocally support the latter, as was the case in 2009. Only a third express their full preference for the continued union with Russia/EEU (a drop of 24 percent), while another third expresses a closer affinity with the EU (a rise by 15 percent). Only 23 percent see benefits of working exclusively with the EUC (a drop by 27 
The EU and Belarus: democracy promotion by technocratic means?

percent), and the plurality (37 percent) believe that partnership with both polities would be of greater benefit for the country.

In summary, five years on $(2009 ; 2013)$ public legitimation of the EU is clearly on the rise reflecting positive changes in attitudinal preferences and behavioural patterns. Particularly noticeable are the rising ideational affinity of the respondents with the EU, and their now comparable treatment of the EU with those of the ECU and Russia. In 2009, as the survey showed, the population was largely uninterested and uninformed about the EU: every fifth respondent had difficulty in naming EU Member States, every second failed to locate the EU headquarters. This radically altered by 2013, attesting to the efforts and benefits of the EU continued low-key engagement with the people, at different levels of social hierarchy. The inclusive and versatile nature of EU projects, instruments and sector cooperation, directly or otherwise, succeeded in awakening a long overdue interest and urge for cooperation, as well as in producing an astounding array of various actors who begin to questions the established status-quo, and those who actively advocate for reciprocal learning space with the EU, and other neighbours.

These new narratives, to a degree, are mirrored by the government discourse, openly recognising the need to pursue a multi-vector foreign policy. As Lukashenko formally declared in 2008, 'the "Golden Rule" of our foreign policy is multi-vectoredness and interest in reciprocal contracts... We are equally keen on cooperating with both the East and the West, and especially the EU',51

This discourse continues - of tacit resistance and clandestine diversification - even at the sight of closer approximation with the ECU and the future EEU, which Belarus feels compelled to ratify given the pressure from Russia. ${ }^{52}$ Government discontent with an increasing co-option into a biding space of the ECU/EEU, has been detected on several occasions, including criticism of Yanukovich's actions towards Maidan, endorsing Poroshenko's presidency, and refusing to support Russia's economic embargo of Ukraine, as mentioned earlier. By now it seems to have become a regular feature of Belarus' policy-making eastward. 
The EU and Belarus: democracy promotion by technocratic means?

This is not to say, that these disjunctures - in public and government discourses - recently emergent in Belarus' external relations, are fully institutionalised to challenge the established order. Much more work is still needed, especially in terms of developing synergies, through shared practices and reciprocal learning, to assure gradual convergence between normative foundations of the EU and Belarus. As the survey indicates, the uncompromising differences, which go back to pre-history, cultural traditions, and ways of living, remain acute explicitly differentiating between the models of liberal democracy and those of non-liberal type. ${ }^{53}$ At the same, signs of convergence, especially in socio-economic terrain, and potential complementarity of the two regional projects - the EaP and the ECU - are gradually translating into the daily narratives of citizens and their governments, to indicate their potential. .

New normative visions, even when simply associating with more stability, prosperity and security rather than highly-politicised values of European democracy, cannot be imposed externally, even by means of most sophisticated social/ideational engineering. It is important on this occasion to recognise and accept the very existence of the non-liberal Other, who can only be socialised rather than compelled into a 'shared mode' of thinking, if sustainable relations were to endure. On part of the EU, this understanding is slowly forging, whereby political conditionality, although still mooted, is now complemented by a technocratic campaign of codification and inculcation of norms and practices into the daily lives of individuals. The EU is expanding its presence in Belarus, and the benefits of incremental socialisation begin to show. At the same time, the EU is still a considerable distance away from understanding that the pursuit of cooperation is not simply about propping up the same political initiatives with new or more instruments or implementing them in a unilateral manner. It is a lengthy and painstaking process of change, through continued assistance but no immediate or significant outcomes to justify commitment. However if commitment is there, social empowerment and norm inculcation may do wanders, which is further explored below. 
The EU and Belarus: democracy promotion by technocratic means?

\section{Further discussion: social empowerment by technocratic means?}

What does the above discussion tell us about the causality of change and of a changing (and contested) nature of democracy promotion? So far we have registered a transforming nature of EU democracy promotion strategy towards Belarus. The analysis of EU engagement with the country did not only uncover its continued and even increasing levels of engagement, undertaken in the circumstances of limited political dialogue, under a much-criticised ENP/EaP. Most crucially, the analysis reveals substantive change in EU modus operandi - from high to a low-level politics - which became more technocratic (and sector-focused), more versatile in its instruments and more inclusive in its structures. The crucial question here whether this shift in EU governance has had any positive effect on regime performance in Belarus?

Further, in our analysis, we also observed gradual change in public attitudes and behavioural patterns, which more recently began to manifest closer affinity with the EU, expressed through rising levels of public awareness, cognizance, interest and emotive approval. There has been also better understanding of the EU as a neighbour and a polity, and important mapping of interests and capacity, by the respondents, has taken place. Most instructively however, there have been significant shifts in identity formation, inclusive of a more critical view of the Self, and a more quizzical view of the Other - the EU and the ECU/Russia in this particular case. A newly emergent public narrative conveys more 'European-ness' amongst the Belarusians, and the urge to become more open-minded and inclusive of both the West and the East, to avoid a hitherto privileged treatment of Russia as a default option.

The above processes of course may or may not be connected: after all, establishing transparent causality in the ontology of beings has always been tricky (some would even argue, impossible). ${ }^{54}$ At the same time, given the coincidence of the time periods - of the shift in EU governance and a subsequent shift in public opinion - as well as the respondents' concrete references to EU specific measures and projects, the bourgeoning number of actors and associated with their activities positivity, one might confidently rationalise the occurring changes in their causal connectivity. Does 
The EU and Belarus: democracy promotion by technocratic means?

it imply that democracy promotion by technocratic means has a precedent today and may even be more effective in some cases? Then, what about the 'values-driven' approach: is a more functionalist engagement towards less-democratic states, tantamount to propping up 'the last dictatorship in Europe', which has so far shown no official remorse or backtracking of its policies?

These questions are worth unpacking here to clarify a number of important tenets for understanding democracy promotion and practice.

Recently, several scholars ${ }^{55}$ have begun to observe critical shifts towards more 'functional' and 'institutionalised' engagement of the EU with autocratic regimes in the Middle East and North Africa, and in the eastern region, with Belarus and Azerbaijan in particular. This development, as Bosse argues in particular, 'is potentially serious, as it appears to mark the beginning of the end of the EU's ambition to act as a successful democratizer in its immediate neighbourhood, and perhaps even the end of the democratizing paradigm in the EU's foreign policies more generally'. ${ }^{56}$ Furthermore, she contends, the EU strategy of functional cooperation 'remains fuzzy' and ad hoc, and simply submitting to what is possible to achieve under the 'circumstances' - controversial goals of ensuring economic and geopolitical benefits for some parties. ${ }^{57}$ The wider picture, however, reiterates a scholarly concern about the EU's credibility as a 'force for good', and may even underscore 'de facto acceptance ... of the limits of Union's role as a "successful democratizer" when the prospect of membership is not within reach'. ${ }^{58}$ These potentially serious concerns over the EU's undermining its own creed, when 'partnering with dictatorships', raise equally serious questions. First, if the current EU policies towards modern autocracies are not working or effective, as many recent cases come to attest, should the EU then withdraw from further engagement with a country-in-question, in order to avoid unpleasant compromises and save its integrity? Surely, a formal recognition of its defeat over securing some legitimation in a country, would be even a greater de facto blow to the EU credibility as a global democracy promoter? Conversely, if the EU policies are not delivering in a particular case, would it not be more expedient to diversify and offer more tailored, non-linear and even inclusive, if necessary, an approach in order to facilitate more interest and understanding of 
The EU and Belarus: democracy promotion by technocratic means?

intentions? Perhaps, when analysing these complex and contested issues of democracy promotion, it may be advisable to consider a wider picture, and when tracing cross-temporal longitudinal developments, also to try and connect multiple societal layers of evidence, within and outside the country, to realise what is truly at stake, or hidden below the surface. As the analysis in this article demonstrated, the EU's changing modus operandi to that of a low-key and more technocratic engagement, which has extended to the all levels of society, and been interest/sector-based, yielded a sea-change transformation in public acceptance of the EU as an equally important player in the eastern region (in conjunction with Russia), and in behavioural patterns displaying more selfawareness and critical reasoning. So, is it, on the EU part, recognition of defeat or rather a differentiated tactic to make democracy promotion work? How does it matter, and more essentially, what needs to be done, after these initial steps are undertaken, to promote more enduring practices of democracy? Using the above evidence, we will consider two particular conceptual dimensions here: one of continued practice of international assistance, and one of social empowerment.

Belarus' case is particularly instructive to discuss the relevance of continued practice of international engagement. Owing to its declining human rights record, the country had practically lived in isolation from the West for almost a decade until the introduction of the ENP, with its two-track engagement. This policy yielded no positive results, and as some would argue, ${ }^{59}$ on the contrary caused regime endurance ('rallying around the flag') and pushed the country deeper into the Russian embrace. The ENP, and especially the EaP, have opened up new opportunities for engagement. As the above evidence attests, the new non-linear approach, perhaps counter-intuitively, especially in the absence of political dialogue, induced public socialisation and recognition of the EU as an alternative to Russia, partner. These policy objectives are clearly long-term, and may be unjustifiably costly, for the incremental and often less-visible outcomes they render. At the same time, the policy of international assistance - low-key and technocratic - speaks volumes first, about the committing party (the EU in this case), and the result when it comes to bear fruit, when finally connected with 'the hearts and minds' of the target countries. But not any international assistance is conducive to the 
The EU and Belarus: democracy promotion by technocratic means?

enduring democratic process, and hence its theorisation is of great importance, especially in the light of recent events in Ukraine. As Jahn argues in her seminal work on rethinking democracy promotion:

'One of the weaknesses of democracy promotion has been its tendency to focus on "impulses, strategies, impacts", to frame the issue either as a matter of foreign policy on the part of liberal states or as a matter of domestic political development in target states. What this framing leaves undertheorised, however, are the relations between sponsors and targets, that is its international dimension'. ${ }^{60}$

It is precisely the framing of international assistance that the article sought to test on the case of EUBelarus relations, in order to better understand the undercurrents at work, and also to explicate the nexus between the international policies of democracy promotion and the changing practices of its reception and implementation in Belarus. Often, a focus on producing a single collective will to overthrow regime may not necessarily engender practices which would add up to making changes feasible or enduring. As Jahn contends, 'while [actions] are often successful in establishing democratic institutions, these institutions are subsequently and frequently used to pursue decidedly illiberal policies'. ${ }^{61}$ Indeed, as the evolution of the EU policy to Belarus testifies, the lack of structured, and inclusive engagement during the early days of the ENP, and especially during the time of Belarus' isolation, had been unproductive, and almost detrimental to the interests of all parties concerned. The role of 'the international', as Jahn insists, is decisive, and simultaneously, sensitive, and has not been sufficiently theorised in conjunction with 'the other' - the target country: 'the international order provides the framework demarcating the possibilities and limits of political and economic development for individual states suggesting that policies of democracy promotion must address these systemic constraints in addition to, and in combinations with, their propaganda of particular strategies on the part of targets and sponsors' ${ }^{62}$ When applied to the case of Belarus, what appears to be decisively positive, is the EU's continued functional engagement - especially through sector cooperation under CIB and cross-border cooperation, as well as RPDs and small-scale projects - which now renders new language of norms and regulations, and engenders new practices and in 
The EU and Belarus: democracy promotion by technocratic means?

some cases, structures. But the instances of joint practice are still new in Belarus, and their frequency should be positively encouraged. For example, it remains unclear why the EURONEST has rejected Belarus' participation in its forums, the value of which, as Petrova and Raube have argued, is essentially about emulating EU practices and inculcating good governance. Being dressed in a language of higher politics, this presents itself as a clearly missed opportunity to develop joint practices between the EU and Belarus stakeholders. There also seems to be little incentivisation occurring to integrate Belarus more closely in the WTO economic community, now that is part of the ECU. Otherwise, nudging the country towards further economic reforms to meet the WTO criteria for membership, could have offered another (and yet) missed opportunity to inculcate international norms into Belarus' daily practices. As Jahn argues, practitioners of democracy promotion "should care at least as much about the WTO" as they do about the impact of assistance for elections or support for civil society'. ${ }^{63}$

If 'the international' matters for codifying people-to-people contacts, and socialising them into the practices of 'good governance', and not as spasmodic occasions but rather as a continuing effort; social empowerment - another dimension explored in this article - works differently but relatedly, to ensure translation of 'interpretive practices' into respective 'performing acts' of the individuals. ${ }^{64}$ As Chandler argues, the analytical framing of 'social empowerment' has been lately revisited to recognise and explore non-linear approaches to democracy promotion. In these frameworks, he contends, the logic works inside-out driven by public resilience, when 'the personal becomes political'. ${ }^{65}$ This is however not in the sense of politicising the issues concerned with the working of democracy, but rather in a reverse order, breaking down democracy to the level of 'the individual' to make it relevant to their daily lives:

'Individuals and communities are to be empowered to reflexively work on their personal choices and practices in order to effect political change. "Political problems" are thereby "depoliticized" and represented as "personal problems" which ca be dealt with by empowered individuals and communities'. ${ }^{66}$ 
The EU and Belarus: democracy promotion by technocratic means?

Democracy, as the new debates affirm, is much more than voting in elections and constitutionalising norms. It is about "the public and individuals and their behaviour and understanding on an "everyday" level'. It is less about building institutions -although they matter to help affix pertinent practices but more so about 'the social production of reflexive autonomous subjects' ${ }^{67}$ It is also less about dragging the problems of democracy (or the lack of it) into the realm of high politics, through 'naming and shaming', or bullying target countries into submission to improve their 'democratic performance' by external means. The binary/dichotomous narratives of political conditionality to date, have been problematic in their effectiveness and sustainability, normally leading to shallow executive decisionmaking (Ukraine in early 2000s), or shutting down boundaries for reciprocation altogether (Belarus until now).

Perhaps what matters instead is fostering daily practices of normality for and by individuals, who when engaged, for example in a problem-solving process of their households, develop new knowledge of 'good governance' or simply share 'good practices' to become more 'solvable' and less tolerant of the existing inadequacies in their daily lives including mismanagement, inequality, corruption or abuse. This is where de-politicisation of democracy - 'the rule of people, by the people and for the people' - is truly vital. As Chandler contends further:

'Democratic politics in a non-linear age is less concerned with representation than with the development of social reasoning. The 'power' which 'the people' are seen to require today is social empowerment: the power to take reasoned and responsive decisions in their everyday lives... In this framing, there is $\mathrm{n}$ limit to the extension of democracy through social capacitybuilding, the "powering" of communities or the empowerment of decision-making individuals'. ${ }^{68}$

Gradual change that we begin to observe in public attitudes and behavioural patterns in Belarus attests to the merits of this approach and also renders some useful insights into how low-level pragmatic engagement with various local stakeholders may alter public understanding of politics, and bring clarity to workings of democracy. To give example, electoral politics in Belarus hitherto revolved 
The EU and Belarus: democracy promotion by technocratic means?

around a single issue of building an opposition to regime: that is, in separating those who desire change from those who would like to keep the status-quo of Lukashenko's regime. This dichotomous politics of garnering a single collective will hitherto has yielded limited interest and commitment from the wider public. In partnership with a neighbouring branch of the National Democratic Institute local activists began to alter their tactics of electoral campaigning during 2013-14. This included issue-based politics, raising problems not of democracy promotion but rather those that were relevant to specific constituencies, and even broken down to individual people. Levels of interest mobilisation and activism began to grow exponentially, even engulfing authorities in seeking solutions to specific 'local problems'. ${ }^{9}$

The same could be said about engaging local interest in various projects of sector cooperation - CIB, CSB, BELMED, RELOAD, just to name a few successful initiatives. Not only do they socialise people into the new practices of 'good governance' and help to improve social welfare; they also expand public knowledge and develop critical reasoning about the Self and the order of things, which soon enough will be challenged through a rise of a new collective identity of the 'future Significant We', ${ }^{70}$ perhaps even along the lines of 'We are part of pan-European space'. What we see now are only the seeds of technocracy, which results to be sure, would not keep waiting for long: new narratives today may become new practice tomorrow synergising public resilience and government vision into a new sustainable democratic future.

\section{Conclusion}

As the old English proverb goes, 'still waters run deep', and exploring this simple wisdom has been instructive in the case of Belarus. On the surface, we seem to observe a long-standing political impasse associated with a seeming lack of progress in EU-Belarus relations, which for twenty years have seen no major change, and are presently further constrained by the new developments eastwards, and the forging of the Eurasian space.

As the above analysis has shown, the surface appears deceptive, revealing deep undercurrents at work. Two particular disjunctures - in government and public narratives - have been instructive to 
The EU and Belarus: democracy promotion by technocratic means?

help establish real undercurrents at work. They first associate with a profound shift in the EU engagement with less-democratic regimes, which, in the case of Belarus, has been enduring, more complex and versatile in the use of new instruments; more inclusive in targeting multiple actors; and more substantive in depoliticising democracy promotion to the level of low-key technocratic engagement and sector cooperation.

This counter-intuitive non-linear approach, paradoxically, and in opposition to much scholarly criticism, succeeded in bringing about some crucial changes in public and government narratives. This is mostly associated with positively transforming public affinity with Europe, more clarity with mapping out joint needs and interests, and more motivation for forging a wider European identity, hitherto missing from public narratives.

These changes may seem insignificant at a glance. At the same time, for those who believe in inculcation of values through continued reciprocation and joint practices, and those who stakes on public resilience and social empowerment, these changes would undoubtedly become most important signifies of synergies that finally begin to sow. The outcomes posit a new turn in democracy promotion politics - long-term, and technocratic - that is, building democracy by other means and via continuing exposure to the international norms and regulations, and their inculcation not necessarily into grand stately structures, but rather, into small but meaningful lives of individuals.

\section{Notes}

\footnotetext{
${ }^{1}$ http://www.freedomhouse.org/report/freedom-world/1998/belarus\#.VA2SZMJdV8E

${ }^{2}$ Wilson 2011; Bennett 2011

${ }^{3}$ Council 1997

${ }^{4}$ Ulakhovich 2003, 3; Danilovich 2006

${ }^{5}$ De facto Belarus was excluded from the framework of bilateral cooperation; while its multilateral regional engagement had been aided by curtailed funds from the European Neighbourhood and
} 
The EU and Belarus: democracy promotion by technocratic means?

Partnership Instrument (ENPI) 2007-2013 and from 2014 - the European Neighbourhood Instrument (ENI). For more information visit http://www.enpi-info.eu/ENI

${ }^{6}$ European Commission 2013a

7 See Yahorau's analysis 2013; and also a CFS position paper http://www.eapcsf.eu/assets/files/News/National Platform Position Paper 2013 EN.pdf

${ }^{8}$ Author's interviews with Commission officials and members of the European Parliament

${ }^{9}$ Dragneva and Wolczuk, 2012, 5

${ }^{10}$ http://rt.com/business/162200-russia-bealrus-kazakhstan-union/

${ }^{11}$ Korosteleva 2011

12 Makey’s interview, 23 July 2013, http://www.belta.by/ru/all_news/politics/Makej-v-Brjusselepodtverdil-printsipialnye-podxody-Belarusi-k-razvitiju-otnoshenij-s-ES_i_641904.html. Also Kupchyna's speech

at

Baku

$\mathrm{EaP}$

summit:

http://mfa.gov.by/en/press/news mfa/fcdf6f3a68f1fd19.html

${ }^{13}$ For recent development see http://www.belinstitute.eu/en/node/2280

14 Lyutova and Tovkailo, Vedomosti, 30 June 2014: www.vedomosti.ru/newsline/news/28324261/ukraina-radelila-tamozhennyj-soyuz

${ }^{15}$ The causation of change is a complex phenomenon which may be triggered by a number of factors. In Belarus' case, a growing public predisposition to the EU should not be solely attributed to the latter's policies alone but rather considered in a wider geo-strategic and economic contexts to account, e.g. for Russia's politics. The focus of this paper however is on the EU factor, which takes discussion of causation beyond its scope

${ }^{16}$ Bosse 2012

${ }^{17}$ Korosteleva 2012; Delcour 2011

${ }^{18}$ This of course, has been further challenged by the events in Ukraine, and the EU's slow-coming reaction to Russia's aggression

${ }^{19}$ Commission 2011 
${ }^{20}$ As transpired from author's interviews with senior EU officials, 2011 revisions indeed signified a 'new turn' in EU policies to the neighbourhood, partially for the reasons presented in the text; but more so, for the new momentum of partnership they had inspired

${ }^{21}$ European Commission 2012a; 2012b

22 http://eeas.europa.eu/top_stories/2014/270614_association_agreement_en.htm

${ }^{23}$ This track has been compromised by the EU's politicisation of the AA with Ukraine on the eve of the Vilnius summit.

24 A new instrument which in 2014 succeeded the European Neighbourhood and Partnership Instrument: $\underline{\text { http://www.enpi-info.eu/main.php?id=27348\&id_type=1 }}$

${ }^{25}$ European Commission 2013b.

${ }^{26}$ Not only has this sum in some cases quadrupled in the past two years, it also equals to about 15 percent of Belarus' nominal GDP 2010, excluding loans and other investments

${ }^{27}$ http://mfa.gov.by/en/press/news mfa/d9b701481c909233.html

${ }^{28}$ European Commission 2012b

${ }^{29}$ ENPI 2012, Annex 3

${ }^{30}$ ENPI 2012; 2011

31 In July 2013 the business forum staged a series of unsanctioned meetings protesting some government's decisions regarding the Eurasian Customs Union, see http://www.rferl.org/content/Belarusian Market Vendors Strike Against New Regulations/1358394.ht ml. The National Platform recently met up to identify new targets for the modernisation plan for Belarus: http://www.eap-csf.eu/en/national-platforms/belarus/

${ }^{32}$ See Casier et al 2014, 6 and 8

${ }^{33}$ European Commission 2012b; 2012c

34 This incidentally has been set up at the Belarusian initiative in 2011. See MFA statement at http://mfa.gov.by/en/organizations/membership/list/f1d2b5ac3e69e36f.html 
The EU and Belarus: democracy promotion by technocratic means?

35 Conference of the Regional and Local Authorities for the Eastern Partnership, see http://cor.europa.eu/en/activities/Pages/corleap.aspx

${ }^{36}$ The EURONEST Parliamentary Assembly is a forum to promote political association and further economic integration between the EU and the East European partners, see http://www.euronest.europarl.europa.eu/euronest/

${ }^{37}$ Petrova and Raube 2014

${ }^{38}$ http://eeas.europa.eu/delegations/belarus/documents/eu_activities_in_belarus.pdf

${ }^{39}$ European Commission 2012d

${ }^{40} \mathrm{http}: / /$ ec.europa.eu/europeaid/sites/devco/files/eap-flyer-results.pdf, 4

${ }^{41}$ European Commission 2013a

${ }^{42}$ European Commission 2013c

${ }^{43}$ European Commission 2012c; 2012d

${ }^{44}$ Petrova and Raube 2014

${ }^{45}$ Commission's Press release, 8 September 2014, 3

${ }^{46}$ Bosse 2012, Youngs 2003, Kubicek 2002

${ }^{47}$ Füle 2013

${ }^{48}$ Duncan 1983, introduction

49 The 2008 survey was funded by the ESRC (RES-061-25-0001) as part of a large project 'Europeanising or securitising the outsiders: assessing the EU's partnership-building approach with Eastern Europe': http://www.aber.ac.uk/en/interpol/research/research-projects/europeanisingsecuritising-outsiders/researchfindings/. A similar survey was applied in June 2013, with the support of the Office for a Democratic Belarus (ODB). The survey included 1000 respondents, and stratified, random and representative of the Belarusian population aged 18+ (urban and rural) by nationality, sex, religion, age and education. For more information see http://www.kent.ac.uk/politics/gec/research/documents/gec-belarus-survey-brief-2013.pdf 50 EU Neighbourhood Barometer East: euneighbourhood.eu/wp- 
The EU and Belarus: democracy promotion by technocratic means?

${ }^{51}$ Lukashenko 2008

${ }^{52}$ http://www.kyivpost.com/content/russia-and-former-soviet-union/russia-belarus-kazakhstan-andarmenia-are-about-to-ratify-the-eurasian-economic-union-364921.html, on 17 September 2014

${ }^{53}$ The new debate on democracy promotion underscores the need to pluralise and contextualise the concept, for its promotion to be enduring. See Kurki for more recent discussion on the contestation and pluralisation of different types of democracy, 2010, 365

${ }^{54}$ Kurki 2008

55 Joffee 2008; Youngs 2003; Pace 2009; Bosse 2012

${ }^{56}$ Bosse 2012, 367

${ }^{57}$ Ibid, 379

${ }^{58}$ Ibid, 380

${ }^{59}$ Julia Korosteleva 2012

${ }^{60}$ Jahn 2012, 686-87

${ }^{61}$ Jahn 2012, 692

${ }^{62}$ Jahn 2012, 702-3

${ }^{63}$ Jahn 2012, 703

${ }^{64}$ Adler and Pouliot 2011

${ }^{65}$ Chandler 2014, 43

${ }^{66}$ Ibid, 44

${ }^{67}$ Ibid, 46

${ }^{68}$ Ibid, 56

${ }^{69}$ Michael Murphy (NDI), presentation at 'Belarus Reality Check', Latvian Ministry of Foreign Affairs, Riga, 11 September 2014

${ }^{70}$ Flockhart 2006 
The EU and Belarus: democracy promotion by technocratic means?

Adler, Emanuel and Pouliot, Vincent (eds.) International Practices. Cambridge: Cambridge

University Press 2011

Bennett, Brian. The Last Dictatorship in Europe: Belarus under Lukashenko. London: Hurst, 2011

Bosse, Giselle. 'A Partnership with Dictatorship: Explaining the Paradigm Shift in EU Policy towards

Belarus', Journal of Common Market Studies, 50 (2013): 367-84

Casier, Tom, Korosteleva, Elena and Whitman, Richard. Building a Stronger Eastern Partnership:

Towards an EaP 2.0. University of Kent: Global Europe Centre Policy Paper, 2012

Chandler, David. 'Democracy Unbound? Non-linear Politics and the Politicization of Everyday Life', European Journal of Social Theory, 17 (2014):42-59

Council of the European Union. Regulations (EC) No 552/97. Brussels, 1997

Danilovich, Alexander. Russian-Belarusian Integration: Playing Games behind the Kremlin Walls. Aldershot: Ashgate, 2006

Delcour, Laure. 'The Institutional Functioning of the Eastern Partnership: an Early Assessment'. Eastern Partnership Review, No.1. Tallinn: Estonian Centre of Eastern Partnership, 2011

Dragneva, Rilka and Wolczuk, Kataryna. Russia, the Eurasian Customs Union and the EU: Cooperation, Stagnation or Rivalry? Briefing Paper, 2012/01, London: Chatham House, 2012 Duncan, Graham (ed.) Democratic Theory and Practice. Cambridge University Press, 1983 European Commission. A New Response to a Changing Neighbourhood, Joint Communication to the European Parliament, the Council, the European Economic and Social Committee and the Committee of the Regions, JOIN (2011) 303. Brussels, 25 May 2011

European Commission. 'The Commission Sets out Cooperation Priorities for the Eastern and the Southern Neighbourhood', Press-release. Brussels: 8 September 2014

European Commission. Eastern Partnership Roadmap 2012-13: the Bilateral Dimension, Joint Communication to the European Parliament, the Council, the European Economic and Social Committee and the Committee of the Regions, JOIN (2012) 109 final, Brussels, 15 May 2012a 
The EU and Belarus: democracy promotion by technocratic means?

European Commission. Eastern Partnership Roadmap 2012-13: the Multilateral Dimension, Joint

Communication to the European Parliament, the Council, the European Economic and Social Committee and the Committee of the Regions, JOIN (2012) 108 final, Brussels, 15 May 2012b

European Commission. Eastern Partnership: A Road to the Autumn 2013 Summit, Joint Communication to the European Parliament, the Council, the European Economic and Social Committee and the Committee of the Regions, JOIN (2012) 13 final, Brussels, 15 May 2012c European Commission. EU Cooperation for a Successful Eastern Partnership. Brussels: DEVCO, $2012 d$

European Commission. ENP Package - Belarus, MEMO/13/244, Brussels: 20 March 2013a

European Commission. ENP: Working towards a Stronger Partnership, Joint Communication to the European Parliament, the Council, the European Economic and Social Committee and the Committee of the Regions, JOIN (2013) 4 final. Brussels: 20 March 2013b

European Commission. New EU support on Health and Development for Belarusian People, 25 July, IP/13/743. Brussels, 2013c

European Neighbourhood and Partnership Instrument. Belarus: National Indicative Programme 2012-13. Brussels: European Union, 2012

European Neighbourhood and Partnership Instrument. National Indicative Programme 2012-13 for Belarus: Concept Note. Brussels: European Commission, 2011

Flockhart, Trinity "'Complex Socialization": a Framework for the Study of State Socialization', European Journal of International Relations, 12(2006):89-118

Füle, Stefan. 'ENP - Priorities and Directions for Change', Speech/13/661, Warsaw: Annual Conference of Polish Ambassadors, 25 July 2013

Jahn, Beate. 'Rethinking Democracy Promotion', Review of International Studies, 38(2012): 685-705

Joffe,George. 'The European Union, Democracy and Counter-Terrorism in Maghreb', Journal of Common Market Studies, 46 (2008):147-71 
The EU and Belarus: democracy promotion by technocratic means?

Korosteleva, Elena. 'Belarusian Foreign Policy in a Time of Crisis', Journal of Communist Politics and Transition Studies, 27(2011): 566-87

Korosteleva, Elena. The European Union and its Eastern Neighbours: Towards a More Ambitious Partnership? London: Routledge, 2012

Korosteleva, Julia. The Impact of Targeted Sanctions on Belarus. Brussels: DG for External Affairs, 2012. http://www.iris-france.org/docs/kfm docs/docs/observatoire-voisinage-europeen/2012-05impact-of-targeted-sanctions-on-belarus.pdf

Kubicek, Paul. The European Union and Democratization. London: Routledge 2002

Kurki, Milia. 'Democracy and Conceptual Contestability: Reconsidering Conceptions of Democracy in Democracy Promotion', International Studies Review, 12 (2010): 362-387

Kurki, Milja. Causation in International Relations: Reclaiming Causal Analysis Cambridge: Cambridge University Press, 2008.

Lukashenko, A. Speech delivered at the meeting with BSU students, Press Release No. 49929, 12 February 2008, http://www.president.gov.by/press49929.print.html

Pace, Michelle. 'Paradoxes and Contradictions in EU Democracy Promotion in the Mediterranean: the Limits of EU Normative Power'. Democratization 16 (2009):39-58

Petrova, Irina, and Raube, 'The EaP, EuroNest and the Inter-Parliamentary Cooperation in the EU Neighbourhood', paper presented at the UACES conference, 1-3 September 2014

Ulakhovich, Vladimir. 'Belarus-Evropeiskiy Soyuz: Sotrudnichestvo v Novykh Usloviyakh', paper presented at joint German-Belarusian conference 'New Policy towards Belarus'. Minsk: Belarusian State University, 2003

Wilson, Andrew. Belarus: the Last European Dictatorhsip. Yale University Press, 2011 Yahorau, Andrei. 'Dialogue Limited to Technical and Diplomatic Level: Belarus', PASOS assessment , 2013. http://www.eapcsf.eu/assets/files/Articles/Web/Roadmapreports/Belarus\%20roadmap\%20monitoring\%20csf\%20n ov\%202013\%20(3).pdf 
The EU and Belarus: democracy promotion by technocratic means?

Youngs, Richard. 'European Approaches to Democracy Assistance: Learning the Right Lessons?'

Third World Quarterly 24 (2003): 127-38 